\title{
Formation and Development of Bilateral Relations of the Republic of Kazakhstan and the People's Republic of China in 1990-e-2000s
}

\author{
Ramil M. Valeev ${ }^{1} \&$ Leysan I. Kadyrova ${ }^{1}$ \\ ${ }^{1}$ Kazan (Volga Region) Federal University, Kazan, Russia \\ Correspondence: Ramil M. Valeev, Kazan (Volga Region) Federal University, Kremlyovskaya street, 18, Kazan \\ 420008, Russia. E-mail: valeev200655@mail.ru; ram.valeev2016@yandex.ru
}

Received: April 14, 2015 Accepted: April 20, 2015 Online Published: April 27, 2015

doi:10.5539/jsd.v8n4p277 URL: http://dx.doi.org/10.5539/jsd.v8n4p277

\begin{abstract}
The urgency of the problem under investigation is determined by the current political situation in the world, strengthening China's position in the international arena, as well as the intensification of its ties with the countries of Central Asia, especially Kazakhstan. The purpose of the article is to analyze the process of formation and development of bilateral ties between China and the Republic of Kazakhstan at the current stage. The leading approach to the investigation of the stated problem is systematic, including the analysis of all aspects of China-Kazakh relations (politics, economy, energy, culture etc.) It allows to estimate objectively the level of the bilateral relations. The article presents the review of the key diplomatic events during the indicated period; it looks through the main regulatory legal acts, it identifies the main fields of bilateral cooperation, it evaluates the nature of their relationships and the most complicated issues and problems, it determines the value of interstate relations in general. The article proceedings are valuable for the authors engaged in international relations, can be used in research on the subject of Central Asia.
\end{abstract}

Keywords: Central Asia, Kazakhstan, The Chinese National Republic, international relations, cooperation

\section{Introduction}

At the present stage, the region of Central Asia is at the center of the world politics, international relations and public attention of the East and the West. Problems of Central Asia are actively discussed not only by the political establishment of the involved countries, but also at various scientific conferences, forums and media worldwide. The region has eventually become to correspond to its name "Central Asia". In this region having specific geopolitical location and rich resource potential, the interests of the leading powers of history and modern system of international relations are facing together. A complex mechanism of political and socio-cultural relations between the states and nations was formed here. One of the most important elements are interstate relations between the Republic of Kazakhstan and The Chinese Republic. Rapidly developing China is actively extending its influence on the world stage, and being the most Asian among the other global leaders, it is highly interested in cooperation with neighboring Central Asian states. Kazakhstan is positioning itself as a leader in the post-Soviet Central Asia, and it mostly corresponds to reality. The most extended common border unites these states. Political, trade, economic and cultural ties between China and Kazakhstan are dominant in Central Asia. The main directions, results and prospects of the interstate relations between Kazakhstan and China are the urgent problem of research of Russian and foreign authors. Traditionally this subject was studied in the post-Soviet period, primarily in Russia and Kazakhstan: K.K.Tokaev (1998), T.A.Tursunbaev (2002), V.V Naumkin (2005), I. Komissina and A. Kurtov (2003), K.Sh.Hafizova (1999) and others. Research carried out by Chinese experts: Shu Yang (2000), Liu Tsintszyan (1998), Zhang Syanlan (2003) and others. The USA's and UK's researches are increasingly focusing on a variety of issues of bilateral relations between Kazakhstan and China. Certain aspects of the topics are highlighted in the works of R. Weitz (2012), A. Haga (2010), D. Shlapentokh (2014), M. Barles (1999), M. Golam (2013), A. Kul (2012) and others.

\section{Methodical Framework}

During research a complex of basic scientific methodological principles and ideas was used for multilateral analysis of the themes of China-Kazakh interstate political relations. The principle of historicism, the comparative historical method and the systematic approach were core points. 
On the basis of historicism the origins and the main stages of bilateral Kazakh-Chinese relations after the collapse of the USSR were studied. The comparative-historical principle let us clarify the formation and development of relations between China and Kazakhstan in the context of the world situation and the major historical events in Central Asia. The method of systematic approach helps to consider all the components of the ties between the two countries in their interrelation and interaction: economy, politics, humanitarian sphere, diplomatic acts, regulatory framework, situation in the region, and so on. These and the other research approaches provide an opportunity to highlight the phenomenon of inter-state relations of the Republic of Kazakhstan and China in 1990-2000 systematically, that makes possible to comprehend its historical and contemporary interaction base, further development trends, problems and prospects.

\section{Results}

The formation of interstate China-Kazakhstan relations began after the collapse of the USSR and right after Kazakhstan gained sovereignty. The starting date was January 3, 1992 - the day the Communique on the Establishment of Diplomatic Relations between the Republic of Kazakhstan and China was signed. Formation and development of bilateral relations between these countries is based on the major regulatory legal documents. Let us highlight the most important agreements of the 1990s - 2000s .: the Joint Communique on the Establishment of Diplomatic Relations between the Republic of Kazakhstan and the Republic of China ( the joint communique on the establishment of diplomatic relations between Kazakhstan and China, 1992), the Joint Declaration on the foundation of friendly relations between the Republic of Kazakhstan and China (the Joint Declaration on Principles of Friendly relations between Kazakhstan and China, 1993), the Agreement between the Republic of Kazakhstan and the Republic of China concerning Chinese-Kazakh state border (the Agreement on Sino-Kazakhstan border, 1994), Additional agreements on Sino-Kazakhstan border (Supplementary Agreement on China-Kazakhstan border, 1997; Supplementary Agreement on China-Kazakhstan border, 1998), the Joint Declaration on further development and the deepening of friendly relations between Kazakhstan and China (the Joint Declaration on further development and the deepening of friendly relations between Kazakhstan and China, 1995), the Joint Declaration of the Republic of Kazakhstan and China (the Joint Declaration of the Republic of Kazakhstan and the Republic of China, 1996), the joint communique on complete settlement of border issues between the Republic of Kazakhstan and the Republic of China (the Joint Communique on the complete settlement of border disputes between Kazakhstan and China, 1999), the Treaty of Friendship and Cooperation between the Republic of Kazakhstan and the Republic of China (the Treaty of Friendship and Cooperation between China and Kazakhstan, 2002), the Agreement between the Republic of Kazakhstan and China on cooperation in the fight against terrorism, separatism and extremism (the Agreement on cooperation in the fight against terrorism, separatism and extremism, 2002), the Agreement between the Republic of Kazakhstan and the Republic of China on the establishment of China-Kazakh Cooperation Committee (Agreement on the establishment of China-Kazakh Cooperation Committee, 2004), the Joint Declaration of the Republic of Kazakhstan and the Republic of China on the establishment and development of strategic partnership (the Joint Declaration of the Republic of Kazakhstan and the Republic of China on the establishment and development of strategic partnership, 2005), the cooperation strategy between Kazakhstan and China in the XXI century (The cooperation strategy between China and Kazakhstan in the XXI century., 2006), The concept of development of economic cooperation between Kazakhstan and China (The concept of development of economic cooperation between China and Kazakhstan, 2006), the Agreement between the Government of the Republic of Kazakhstan and the Government of the Chinese Republic concerning cooperation in the peaceful uses of nuclear energy (the Agreement between the Government of the Republic of Kazakhstan and the Government of the Republic of China on Cooperation in the Peaceful Uses of Atomic Energy, 2011), and others.

The chronological development of bilateral relations between China and Kazakhstan can be divided into several stages: the 90s of the twentieth century - a period of formation of the relations between the two countries, signing of the principal agreements and decisions concerning the key issues (border settlement, migration, economic cooperation, and others). The first half of the 90 s was mostly characterized by bilateral agreements, and the other half - the interaction in a multilateral format (regional associations). The $2000 \mathrm{~s}$ - a period of the deepening and intensification of cooperation in various fields (trade, energy, humanitarian sphere and others), it was a stage of strategic partnership between the two countries.

Active joint efforts began immediately right after the establishment of diplomatic ties. In 1992 the meetings of senior representatives of both countries and negotiations concerning priority issues of cooperation and border settlement were held. In autumn of 1993 President of Kazakhstan Nursultan Nazarbayev paid his first official visit to China, during which the parties have agreed on Principles of Friendly Relations and issued this document as the first joint declaration. In 1994 premier of the Chinese State Council Li Peng visited Kazakhstan. The 
outcome of the high-leveled negotiations was the decision of the border issue, the two sides agreed on the China-Kazakh border. The 1995 was marked by the official announcement of the Chinese leadership to provide security guarantees for independent Kazakhstan. Nursultan Nazarbayev visited Beijing, during which a Declaration on the further development and deepening of friendly relations between the two countries was adopted. In 1996 the head of China Jiang Zemin made a return visit to Kazakhstan, and this year was characterized by the intensification of cooperation between the two countries in the multilateral format (Agreement on Confidence-Building Measures in the military field between China, Kazakhstan, Kyrgyzstan, Tajikistan and the Russian Federation). In 1997 cooperation in the oil and energy sectors was significantly extended, the process of establishing a common China-Kazakh border continued. Negotiations on the border issues were completed in 1998, the leadership of the two countries began to pay attention to the issues of tourism, joint research projects and vital interaction within the Shanghai Five. In 1999 the official statement of the two sides on the full settlement of border disputes as well as agreements on the further cooperation in the twenty-first century were announced. In 2000 agreements on economic assistance to Kazakhstan from China were signed. In 2001 Kazakhstan and China, jointly with Russia, Kyrgyzstan, Uzbekistan and Tajikistan have decided to form a new regional association - the Shanghai Cooperation Organization (SCO). The further cooperation within the SCO has become permanent. Regional interaction has become one of the priorities. In 2002 Nazarbayev visited China again and signed the Treaty of Friendship and Cooperation. At the same time the parties have issued security arrangements. In 2003, President Hu Jintao's paid a return visit to Kazakhstan. Agreement to provide a grant assistance for the Government of Kazakhstan from the Government of Chinese Republic was signed. In 2004 Nursultan Nazarbayev once again visited China, and the heads of two countries approved the creation of the Kazakh-Chinese Cooperation Committee. There was a state visit of Hu Jintao to the Republic of Kazakhstan in the summer of 2005. The sides held a discussion upon the issues of establishment and development of strategic partnership and confirmed it with an appropriate document. In the same year several agreements on the joint fight against crime were adopted as well as it was announced about the establishment of the Consulate General of Kazakhstan in Shanghai. A number of fundamentally important documents on cooperation between the countries in general and in individual sectors (trade, transport, culture and so on) were signed in 2006. In August 2007 it was decided to establish the Consulate General of China in Almaty and joint efforts were carried out in order to build a gas pipeline Kazakhstan - China. In 2008 the leaderships of these countries approved an implementation plan for bilateral cooperation in non-resource sector of the economy. Prime Minister Karim Massimov visited China and Premier of Chinese State Council Wen Jiabao - the Republic of Kazakhstan. Some agreements upon the Kazakh-Chinese Cooperation Committee (2004) were modified. Then in 2009 the leaderships of the two countries approved appropriate changes and additions to the Framework Agreement on the development of comprehensive cooperation in the field of oil and gas. In summer of $2010 \mathrm{Hu}$ Jintao announced his proposal for the further development of a strategic partnership between China and Kazakhstan (5 points). Some agreements in the field of custom sphere and health were signed. In 2011 Nursultan Nazarbayev paid a visit to China, the leaders summarized the results of the previous years and discussed the possibilities for the future development of strategic partnership. In 2012 on the border between the states railway crossing Altynkol Khorgos was opened. Thus, a new transit route from China through Kazakhstan to Europe appeared. In 2013 the President of Kazakhstan Nursultan Nazarbayev paid an official visit to China, and the head of the Chinese Republic Xi Jinping visited Kazakhstan. Leaders discussed the issues of bilateral and multilateral cooperation. They paid much attention to the projects in the energy sector. In 2014 there were several meetings between Nursultan Nazarbayev and Xi Jinping. On September 122014 the leaders discussed some urgent issues during a meeting in Dushanbe, particularly, the draft of economic zone "Silk Road", the cooperation within the SCO framework, and other areas of mutual interests.

It should be noted that in the first years after Kazakhstan got its independence the Chinese government has behaved with extreme caution in the process of establishing ties with the young republic. China during that time "watched" a new neighbor, probed the ground for the future development of relations. It was important that China estimated Kazakhstan as the sphere of Russia's interests and couldn't afford itself to make any claims on to the former Soviet republic. However, it turned out that the Russian Federation was reoriented to the West and Central Asian direction wasn't of great concern for Moscow. Such situation in the first half of the 1990s allowed China to behave more boldly towards Kazakhstan and the other Central Asian republics.

The second half of the 1990s was marked by a tendency to intensify trade and economic relations between China and Kazakhstan. China's leadership sees the potential of Kazakhstan as a market for products, as well as a partner for joint infrastructure projects. In the late 1990s - early 2000s China provided Kazakhstan with grant financial aid. 2001 is treated as a milestone for the development of China-Kazakh political relations because $\mathrm{SCO}$ was formed. Before that multilateral cooperation was blurred, but after that it took shape in a certain frame 
and became an important part of the foreign policy of two countries. In 2002 China and Kazakhstan signed the Treaty of Friendship and Cooperation, which marked the beginning phase of the deepening and expanding bilateral ties. In the first decade of the 2000s trade and economic sphere, as well as cooperation at the level of departments was becoming more and more important. By the beginning of the second decade cooperation in the oil and gas industry has become important. For instance, during a tour of the new leader Xi Jinping around Central Asian region, China and Kazakhstan parties entered into more than thirty agreements worth approximately $\$ 22$ billion US dollars.

Cooperation in trade and economic spheres between countries is intensively developing. The first agreement on cooperation in the oil and gas field was signed by the leaderships in 1997. At the same time initial agreements concerning joint projects for the development of oil fields and the construction of oil pipelines were reached. Nowadays Kazakhstan is the second one after Russia in trade with China among the CIS members, and China takes the first place among the trade partners of Kazakhstan. In 2006 a pipeline Kazakhstan - China ( Atyrau Alashankou, part of the project pipeline Central Asia - China) started to work. The pipeline has a capacity of 10 million tons per year, with a gradual increase in the future. Several major Chinese oil companies work in Kazakhstan such as Sinopec (China Petrochemical Corporation), CNOOC (China National Offshore Oil Corporation), and others. According to the statistics the rate of bilateral trade between two countries is growing: in 2007 it was 14 billion US dollars, which is 36 times more than in 1992 (Hug, 2010). Cooperation in the field of energy is rapidly developing. Kazakhstan is among the ten largest suppliers of oil to China. In 2011224 thousand barrels of oil per day (Karsybekov 2013) were delivered from Kazakhstan to China, and China was the second importer of Kazakh oil. It is projected that by 2020 the export of Kazakh oil to China can be up to 13 million tons. China and Kazakhstan are developing projects in the field of hydropower, for example, the construction of hydropower plants on the river Charyn and Ekibastuz. Projects are very promising, but today, due to disagreements between the sides, its implementation is frozen. Coperation in the field of nuclear energy is developing too. Kazakh company "Kazatomprom" is one of the most important participants of the projects for the construction of nuclear power stations in China. Joint development of rich uranium reserves in Kazakhstan is carried out together. So, China-Kazakh relations comprise various areas of energy cooperation.

Cooperation in the field of non-raw materials is also developing - building materials, roads, transport, machinery, chemicals, metallurgy, oil and gas processing, technology, agriculture. Leaders of the two countries are also trying to strengthen mutual contacts in the humanitarian sphere, particularly in the field of education (student exchanges, cultural centers, cultural days, etc.) and tourism (popularization of local attractions and nature reserves). China-Kazakhhumanitarian ties are actively expanding from the 2000s. This was possible thanks to the adoption in 2001 of action plan for the expansion of bilateral cultural exchange. Official events are actively and widely held (Days of Culture of Kazakhstan in China and Chinese Culture Days in Kazakhstan). Numerous student exchange programs are put on a stream, specialized educational institutions are opened (Confucius Institutes in Kazakhstan), in the two countries neighbor national media (newspapers, radio) appear, translation of the masterpieces of modern literature and literary works of the neighboring country is organized. In this case, it is still necessary to note that in this area there is a clear advantage to China. While the constant growth of interest in the study of the Chinese language (currently in Kazakhstan four of the Confucius Institute and several classes of Confucius are functioning, there are also many educational programs for high school students and a variety of private courses for those who wish to learn the Chinese language) and receiving education in China (in Chinese universities and institutes more than 8,000 Kazakh students are studying, Kazakh pupils are studying in Chinese schools), the Kazakh language in China remains the prerogative only of the Kazakhs and a few students of specialized departments, and the Chinese are going to Kazakhstan often to study the Russian language. The same situation is with tourism. Number of Kazakh tourists in China is growing every year (Kazakhs go just to relax and get medical care as well.) In 2003, there were 32 flights between the two countries. A Kazakh trend in China's tourism sector does not have such a demand. Kazakhstan's leadership is trying in every way to change the situation in the future and attract the Chinese people to their territory (Astana, Almaty and Aktau, parks and resorts).

Despite the stable development of relations between the two countries, economic and political problems continue to exist. One of the most controversial and unresolved difficulties at the present stage is the problem of transboundary rivers. The question was raised in 1992, immediately after the establishment of diplomatic contacts. Kazakhstan's leadership has sent a draft agreement to the Chinese side, "Proposals for consultation on the joint use of transboundary rivers." These projects are regularly offered by Kazakhstan, but Beijing doesn't give any specific answer. Chinese diplomats said evasively that "the issue is studied" constantly delaying negotiations indefinitely. Kazakhstan had an intention to cope with this issue together with Russia because this is 
a common problem of the three countries, but China was against it, insisting on a bilateral format. $\mathrm{n} 1999$ the real bilateral consultations on transboundary rivers between Kazakhstan and China began. It was a kind of achievement. The Chinese side assured that they will not tolerate abuse of neighbor. For negotiations on a permanent basis a joint China-KazakhCommission on the use and protection of transboundary rivers was formed. The first document in the history of the issue was signed in 2001 - Agreement between the Government of the Republic of Kazakhstan and the Government of China on cooperation in the area of usage and protection of transboundary rivers. The leadership of Kazakhstan positively assessed the fact of the start of negotiations and agreements that were reached. However, the problem was not solved in fact. China is in no hurry with the conclusion of the final contract, as well as in reality almost does not perform any obligation, continuing its line of unilateral use of water resources. The main danger is that the lack of a rigid position of Kazakhstan and persistence in this matter may eventually lead to irreversible consequences for the environment, landscape, nature and life of the population that will have an impact on the stability of the region pollution and water scarcity will lead to social tensions, which will cause political tensions.

Difficult aspect of bilateral relations is the situation around the Xinjiang Uygur Autonomous Region of China. Separatism in Xinjiang inflicts damage of the security of both the China and neighboring Kazakhstan and Central Asia. Sprawling Uighur separatism undermines the stability of all involved parties. This increases the risk of acute sub-regional conflict, which is absolutely not positive neither for Kazakhstan nor for China. and forces them to look at this issue constantly. For the first time the term "separatism" appeared in the Joint Declaration of 1995, although the issue had been discussed before at all levels. The parties announced a mutual decision to oppose any kind of national separatism, preventing in their territory activities of any organization directed against other separatists. This postulate was enshrined in the joint documents in subsequent years. In the 2000s discussion of ways to solve the problem of Uyghur separatism and implementation of the relevant agreements were made within the Shanghai Cooperation Organization as it gives the opportunity to combine the efforts of several stakeholders in the fight against separatism. Xinjiang - an obvious potential hotbed of ethnic and religious conflict, which is equally dangerous for China and neighboring Kazakhstan, as well as for the whole of Central Asia, which requires both bilateral China-Kazakh and multilateral (SCO) search of methods of a solution.

Relevant factor in bilateral relations is cross-border ethnic groups. As it is noted by R. Weitz "general ethnic groups are a unique feature that distinguishes the relations between China and Kazakhstan from other countries in Central Asia» (Weitz, 2012). Historically, ethnic groups on the border between the two countries are strongly mixed and intertwined. In China there is the largest in the world Kazakh Diaspora (at last count, about 1.5 million. People). In Kazakhstan there are up to $70 \%$ of all Uighurs CIS. Law and humanitarian aspects of Kazakhs living in China, the problem of their return to their historical motherland (repatriation), activity of Uighur separatist organizations in the territory of Kazakhstan, their close ties with the separatist movements in Xinjiang of China and many other difficult issues remain to be key points in international relations of the two countries.

The relationship of each party to the other states on the territory of Kazakhstan - Russia, the US, Muslim countries and the neighboring Central Asian republics had an effect on the formation and development of bilateral relations between Kazakhstan and China. Kazakhstan supports the international balance between China, the Russian Federation, USA, Turkey and Iran. China is interested in expanding its influence in Kazakhstan, but also takes into account the historical, political, economic and cultural ties between Russia and Kazakhstan.

\section{Discussions}

In the view of the current political situation in the world the theme of growing Chinese presence in Central Asia attracts the attention of the public in various countries. China-Kazakh relations as a part of the Sino-Central Asian policy are actively discussed by various experts outside of Kazakhstan and China. The special interest of the West in this issue is being observed now, primarily in the US, due to American ambitions in the region. In Russia, the Sino-Central Asian relations are a constant topic of discussion due to geographic proximity and historical ties. However, there are no studies devoted entirely to interstate relations of China and Kazakhstan in the period $1990-2000$ 's. Multilateral and deep examination of all aspects of bilateral relations of China and Kazakhstan will be increasingly in demand in the science of history, political science, and others.

\section{Conclusion}

In the 1990s - 2000s The Republic of Kazakhstan and China implemented promising measures to promote long-term bilateral relations. This is evidenced by the current high level of political relations. Formation and development of bilateral relations between Kazakhstan and China are stable and progressive. The presence of 
some unresolved issues does not prevent full cooperation in general. Because of this many-sided situation in the world and in the region at the present stage it is difficult to predict and assume in what way the China-Kazakhrelations will develop. It is unlikely that there is a real threat to Chinese dominance in the region in general and Kazakhstan in particular, at least the total. Kazakhstan itself is not interested in it because the fear of Chinese expansion is still present in society and political circles, neighbors, and this greatly hinders the development of relations. Economic presence of China in the Republic of Kazakhstan will continue to increase, particularly in the energy sector and infrastructure projects. In the future inter-state political, economic and cultural relations will be strengthened in many directions due to diplomatic visit the new Chinese leader Xi Jinping to the Central Asian republics in 2013.

\section{Recommendations}

The contents of this article may be useful for researchers who are interested in Central Asia, China's foreign policy, China's policy in Central Asia, the history of modern Kazakhstan and its foreign policy priorities, as well as for experts who deal with Russian policy in Central Asia.

\section{Acknowledgments}

The work is performed according to the Russian Government Program of Competitive Growth of Kazan Federal University.

\section{References}

Burles, M. (1999). Chinese Policy toward Russia and the Central Asian Republics. Washington.

Cooley Alexander. (2012). Great Games, Local Rules: The New Great Power Contest in Central Asia. New York.

Dogovor o dobrososedstve, druzhbe i sotrudnichestve mezhdu Kitaem i Khazahstanom. (2002 г.). Retrieved March 9, 2015, from www. kazakhstan.news-city.info/docs/sistemsx/dok_iedhai.htm.

Dopolnitelnoe soglashenie o kitaysko-kazahstanskoy gosudarstvennoy granitce. (1997). Retrieved March 9, 2015, from www.//adilet.zan.kz/rus/docs/Z990000352

Dopolnitelnoe soglashenie o kitaysko-kazahstanskoy gosudarstvennoy granitce. (1998). Retrieved March 9, 2015, from www.adilet.zan.kz/rus/docs/Z990000351_

Golam Mostafa. (2013). The concept of 'Eurasia': Kazakhstan's Eurasian policy and its implications. Journal of Eurasian Studies, 4, 160-170. http://dx.doi.org/10.1016/j.euras.2013.03.006

Hug Adam. (2010). Kazakhstan at a Crossroads. London.

Karsibekov E. Dolya Khazahstana v neftyanom sektore Kitaia. Retrieved March 9, 2015, from www.centrasia.ru/newsA.php?st=1362640380

Khafizova, K. Sh. (1999). Kazahstansko-kitayskaia granitsa v proshlom i segodnia. Mnogomernie granitsi Czentralnoi Azii. Moskva, 192-196.

Komissina, I., \& Kurtov, A. (2003). Kitai i Tcentralnaia Aziia: problemi i perspectiv sotrudnichestva. Novya Evrasia, 15, 36-38.

Konzceptsia razvitiya economicheskogo sotrudnichestva mezhdu Kitaem i Khazahstanom. (2006). Retrieved March 9, 2015, from www.circ.gov.cn/web/site0/tab129/info40459.htm

Liu, Q. J. (1998). Sino-Central Asian Trade and Economic Relations. Ethnic challenges beyond borders, Chinese and Russian Perspectives of the Central Asian Conundrum. London: 179-200.

Naumkin, V. V. (2005). Tcentralnaia Aziia v mirovoi politike. Moskva.

Shlapentokh D. Kazakhstan drifts to China Amid tension with Russia. Retrieved March 9, 2015, from www.cacianalyst.org/publications/analytical-articles/item/12888-kazakhstan-drifts-to-china-amid-tension-wit h-russia.html

Soglashenie mezhdu Pravitelstvom Respubliki Khazahstan i Pravitelstvom Kitaiskoy narodnoi Respubliki o sotrudnichestve v oblasti mirnogo ispolzovania atomnoi energii. (2011). Retrieved March 9, 2015, from www.adilet.zan.kz/rus/docs/P1100000244

Soglashenie o kitaysko-kazahstanskoy gosudarstvennoi granitse. (1994). Retrieved March 9, 2015, from www.online.zakon.kz/Document/?doc_id=1016993\&sublink=40000

Soglashenie o sotrudnichestve v oblasti borbi s terrorizmom, separatizmom i ekstremizmom. (2002). Retrieved March 9, 2015, from www.adilet.zan.kz/rus/docs/U030001098 
Soglashenie o sozdanii kitaysko-kazahstanskogo komiteta po sotrudnichestvu. (2004). Retrieved March 9, 2015, from www.online.zakon.kz/Document/?doc_id=1048115

Sovmestnoe kommiunike ob ustanovlenii diplomaticheskih otnoshenii mezhdu RK i KNR. (1992). Retrieved from http://online.zakon.kz/Document/?doc_id=1028951

Sovmestnoe kommiunike o polnom uregulirovanii pogranichnih voprosov mezhdu RK i KNR. (1999). Retrieved March 9, 2015, from www.news.sina.com.cn/china/1999-11-23/34546.html

Sovmestnya declaratcia ob osnovah druzhestvennih vzaimootnoshenii mezhdu Respublikoi Khazahstan i Kitaiskoy narodnoi Respublikoi. (1993). Retrieved March 9, 2015, from www.online.zakon.kz/Document/?doc_id=1025860

Sovmestnya deklaratcia Respubliki Khazahstan i Kitaiskoy narodnoi Respubliki. (1996). Retrieved March 9, 2015, from www.kazakhstan.news-city.info/docs/sistemsl/dok_pegnxz.htm

Sovmestnya deklaratcia Respubliki Khazahstan i Kitaiskoy narodnoi Respubliki ob ustanovlenii i razvitii strategicheskogo partnerstva. (2005). Retrieved March 9, 2015, from www.online.zakon.kz/Document/?doc_id=30033087

Sovmestnya deklarazcia o dalneishem razvitii i uglublenii druzhestvennih vzaimootnoshenii mezhdu RK i KNR. (1995). Retrieved March 9, 2015, from www.online.zakon.kz/Document/?doc_id=1021573

Strategia sotrudnichestve mezhdu Kitaem i Khazahstanom v XXI в. (2006 г.). Retrieved March 9, 2015, from www.fmprc.gov.cn/mfa_chn/ziliao_611306/1179_611310/t352850.shtml

Tokaev, K. K. (1998). Osnovnie aspekti protsessa stanovlenia i razvitia vneshnei politiki Respubliki Khazahstan. Actualnie problem vneshnei politiki Respubliki Khazahstan. Moskva: 11-33.

Tursunbaev, T. A. (2002). Mezhdunarodnie sviazi Respubliki Khazahstan. Moskva

Weitz R. The underappreciated China-Kazakhstan Partnership. Retrieved March 9, 2015, from www.chinausfocus.com/foreign-policy/the-underappreciated-china-kazakhstan-partnership/

Yan, S. (2000). Kitai i Kaspii. Kontinent, 21. Retrieved March 9, 2015, from www.continent.kz/2000/21/24.html

Zhang Xianliang. Zhongguo yu Hasakesitan liangguo guanxi.(Otnoshenia mezhdu Kitaem i Khazahstanom). Retrieved March 9, 2015, from www.lw23.com/lunwen_119542352/

\section{Copyrights}

Copyright for this article is retained by the author(s), with first publication rights granted to the journal.

This is an open-access article distributed under the terms and conditions of the Creative Commons Attribution license (http://creativecommons.org/licenses/by/3.0/). 